\title{
Shade trees decrease pest abundances on brassica crops in Kenya
}

\author{
Solène Guenat $₫$ - Riikka Kaartinen $\cdot$ Mattias Jonsson
}

Received: 11 May 2017/Accepted: 19 November 2017/Published online: 24 November 2017

(C) The Author(s) 2017. This article is an open access publication

\begin{abstract}
Agroforestry practices may mitigate the current loss of biodiversity and ecosystem services due to deforestation and agricultural intensification. To examine the effects of agroforestry on the ecosystem service of pest regulation, we assessed pest abundances and biological control potential in shaded and open kale (Brassica oleracea L. acephala) fields in Western Kenya. Specifically, we compared the abundance of pest aphids and caterpillars, ground-dwelling ants, spiders and predatory beetles, and examined aphid parasitism rates, predation rates on diamondback moth eggs, attack rates on surrogate caterpillars and bird predation on aphids. Shade trees effectively reduced abundances of aphids, caterpillars and increased abundances of spiders and predatory beetles, but neither affected ant abundances, or predation and parasitism rates. Our results suggest that presence of shade trees can decrease pest abundances, but that this is not only due to improved biological control by natural enemies but also due to microclimatic conditions affecting pest performance and bottom-up
\end{abstract}

S. Guenat · R. Kaartinen - M. Jonsson

Department of Ecology, Swedish University of Agricultural Sciences, P.O. Box 7044, 75007 Uppsala, Sweden

Present Address:

S. Guenat $(\square)$

School of Earth and Environment, Sustainability Research Institute, University of Leeds, Leeds LS2 9JT, UK

e-mail: eesgu@leeds.ac.uk processes such as changes in plant quality and soil conditions. We encourage studies exploring simultaneously how top-down and bottom-up processes affect pest regulation in agroforestry settings.

Keywords Agroforestry - Aphids - Pest control . Brassica olearacea var. acephala · Parasitism . Predation

\section{Introduction}

Increased cover of agricultural land-use, occurring mainly at the expense of natural habitats, and agricultural intensification are primary causes for the current biodiversity loss and degradation of ecosystem services (Foley et al. 2005). Decreasing biodiversity is likely to trigger a negative feedback on agricultural production, which could decrease agricultural yields in the long-term (Matson et al. 1997). A change towards more sustainable practices, including improved management of ecosystem services, is thus required (Bommarco et al. 2013).

Agroforestry is a land management practice whereby woody perennials are planted together with crops and/or livestock (Lundgren 1982). It can enhance several ecosystem services, including pest regulation (Schroth et al. 2000; Tscharntke et al. 2011; Pumariño et al. 2015; Kuyah et al. 2016). The 
increased habitat complexity in agroforestry plantations compared to monocultures has the potential to increase natural predator and parasitoid populations by providing shelter and alternative food sources (Landis et al. 2000). The dispersal of natural enemies through agricultural landscapes can also be affected by the presence, size, composition and spatial arrangement of agroforestry patches (Dunning et al. 1992). Many studies have shown that landscape complexity and presence of trees in agricultural habitats can improve regulation of specific pests (Bianchi et al. 2006; Tscharntke et al. 2011; Pumariño et al. 2015) in both temperate and tropical climates, with crops as diverse as cabbage and coffee, and with natural enemies ranging from vertebrates (birds and bats) to invertebrates (parasitic wasps, ants, hoverflies and spiders) (e.g. Bianchi et al. 2006; Tscharntke et al. 2011; Bisseleua et al. 2013; Alignier et al. 2014). However, implementation of perennial agroforestry practices can also reduce opportunities for pest regulation achieved through disturbances, such as crop rotations or tillage (Schroth et al. 2000). Other mechanisms such as modification of micro-climate or changes in crop nutritional value can also explain differences in pest regulation between agroforestry and conventional practices (Schroth et al. 2000).

Kale (Brassica olearacea L. var. acephala, Brassicaceae) is an important food crop in Western Kenya, with $80 \%$ of Kenyan crucifers consumed locally (Salasya and Burger 2010). Crucifers are known to host more pests than most other crops. Aphids (Hemiptera: Aphididae) and moth caterpillars, including the diamondback moth Plutella xylostella L. (Lepidoptera: Plutellidae), are among the most abundant pests in Kenyan brassica crops (Kibata 1997; Badenes-Perez and Shelton 2006; Ndang'ang'a et al. 2013). These pests are mainly managed with insecticides, which are used by at least $80 \%$ of all Kenyan farmers producing crucifers (Nyambo et al. 1996; Badenes-Perez and Shelton 2006). The cost of such insecticides average $14.1 \%$ of the total production costs and can thus be a burden for small-scale farmers (Badenes-Perez and Shelton 2006). Most of the insecticides used in Kenya are also known to have a high negative environmental impact (Badenes-Perez and Shelton 2006). Development of more sustainable pest management practices in this system is therefore needed.
Here, we assess the effect of presence of shade trees on pest regulation in kale fields of Western Kenya. We examine pest abundances (aphids and free-feeding caterpillars) and biological control potential by estimating bird predation on aphids and caterpillars, egg predation by ground-dwelling arthropods and predator attack rates on surrogate caterpillars. We also assessed aphid parasitism rates and activity-density of grounddwelling predators. We hypothesized that fields surrounded by shade trees would experience higher pest predation and parasitism rates and host higher abundances of predators compared to sun exposed fields, while sun exposed fields would host higher abundances of pests.

\section{Materials and methods}

Study site

The study was conducted in the Trans-Nzoia district in Western Kenya (Fig. 1a), approximately $15 \mathrm{~km}$ east of Kitale town $\left(01^{\circ} 00^{\prime} \mathrm{N} 35^{\circ} 00^{\prime} \mathrm{E}\right)$. The area is located at $1800-1900 \mathrm{~m}$ a.s.l. and with a mean annual temperature of $19{ }^{\circ} \mathrm{C}$. The average yearly rainfall is $1000-1200 \mathrm{~mm}$, of which the majority falls during one rainy season, from mid-March to October (Jaetzold et al. 2006).

We carried out the work at the settlements Botwa, Hututu, Wehoya, Yuya and Sinoko (Fig. 1b). Agroforestry practices have been promoted in these settlements by the NGO Vi-Agroforestry since the $1980 \mathrm{~s}$, and the landscape structure is characterised by a landscape dominated by small agricultural fields, homesteads and scattered trees. The trees grown on the farms are both native and exotic species providing fruits, timber and nitrogen-fixation. In this region, maize is the main crop, sometimes inter-cropped with beans. Small plots with kale are grown by most farmers. All farmers had used chemical pesticides at least once on their kale fields, but the frequency of pesticide-use varied among farms and was independent of shading conditions.

\section{Study design}

We selected one study field from each of four farms per settlement (i.e., 20 fields in total), with a minimum distance of $100 \mathrm{~m}$ between each field and within 


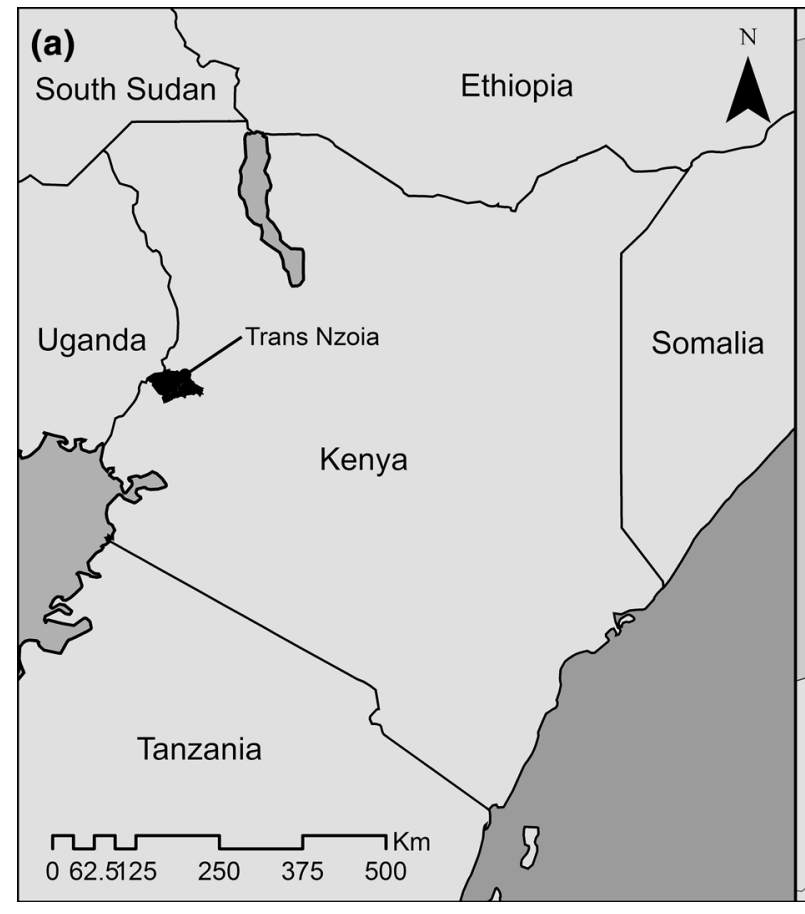

Fig. 1 Map of a the Trans Nzoia region within Kenya and $\mathbf{b}$ the five studied settlements (Botwa, Sinoko, Hotutu, Wehoya and Yuya) within the Trans Nzoia region and in relation to Kitale (b)

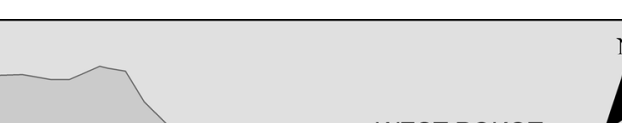

$\mathrm{N}$ 1

WEST POKOT

ARAKWET

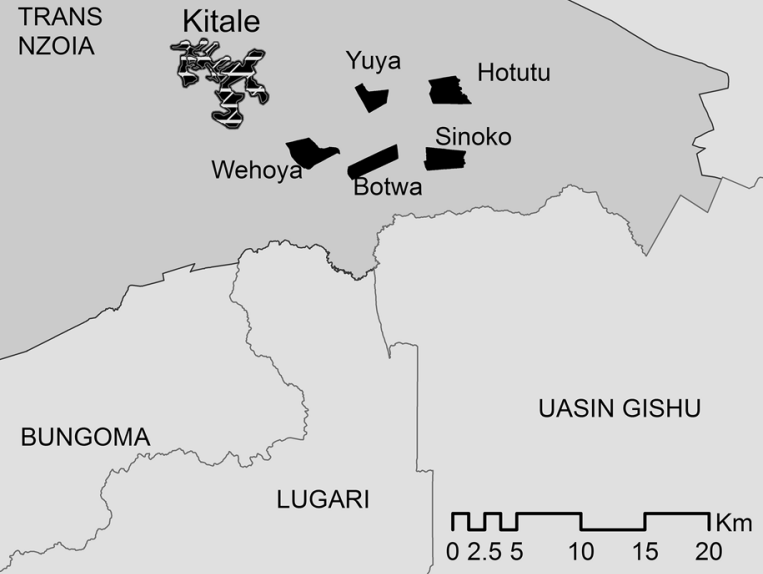

town. Two fields with shade trees and two without were assessed in Botwa, Sinoko and Wehoya, whereas three shaded and one open field were assessed in Hotuto and Yuya

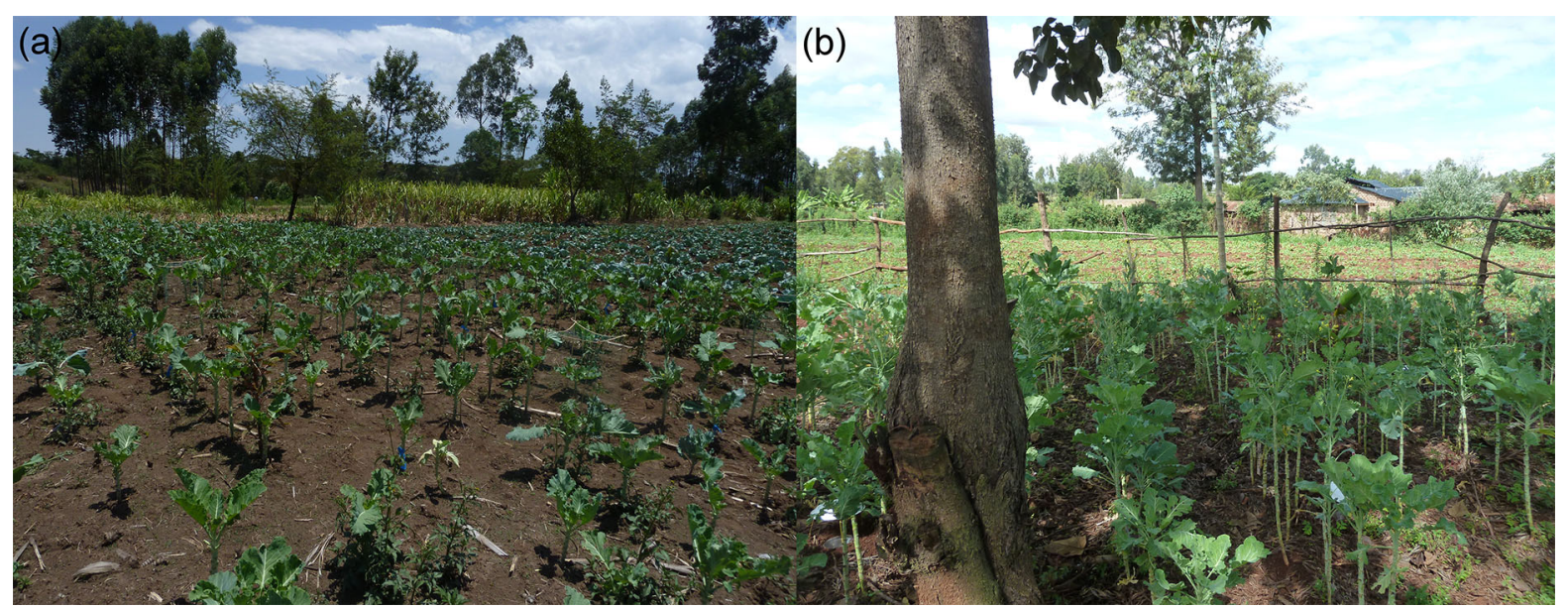

Fig. 2 Illustration of the two treatments: $\mathbf{a}$ an open field, in Hotutu, and $\mathbf{b}$ a field surrounded by shade trees, in Yuya

landscapes of similar complexity. The selected fields, of sizes varying from 20 to $100 \mathrm{~m}^{2}$, all contained kale crops approximately $40-50 \mathrm{~cm}$ high throughout the experiment.

Each selected field was classified as being either shaded by trees or open during most of the hours of the day, by pre-classifying them visually during a first visit and confirming the categorisation after a minimum of five visits during data collection. Two fields in Botwa, Sinoko and Wehoya and one in Hotuto and Yuya, amounting to a total of eight fields, were not surrounded by any shading trees and were thus considered open. The twelve remaining fields had shade trees planted at close to regular intervals around 
the perimeter and, in six cases, trees were present within the field as well (Fig. 2). Shade trees were at least $2 \mathrm{~m}$ high and in most cases had overarching branches. The trees consequently shaded the crops during most of the day. The tree species at the perimeter and within the fields included gum trees (Eucalyptus spp.), riverhemps (Sesbania spp.), avocado trees (Persea americana), palm trees (Arecea spp.), silky oaks (Grevilla robusta) and banana trees (Musa spp.). None of the fields were shaded by buildings or by any artificial shading systems such as nets. The order at which the fields were sampled was random, with shaded and open sites sampled within the same time intervals. All fieldwork was conducted in March and April 2014.

\section{Pest and predator densities}

At each field, the number of foliage-dwelling pests was assessed.

The number of aphids per leaf was counted on two occasion with a minimum of 12 days between counts on randomly chosen kale plants interspersed with at least $1 \mathrm{~m}$. The first count took place from 6th-28th March and included one leaf per plant from a maximum of 50 plants or up to a maximum of 1000 aphids across plants, at which point the count ended at the end of the leaf where 1000 aphids had been counted (mean no. of leaves counted $\pm \mathrm{SE}$, $42.2 \pm 2.8$ ). The second count, took place from 7 th23rd April, following the same rules of counting up to 1000 aphids or the 50th leaf, but covered a whole plant instead of one leaf per plant, and a minimum of five plants per field.

Moth caterpillars, the only other invertebrate pest observed during the study, was counted simultaneously with aphids during their second count.

The activity-density and composition of grounddwelling predatory invertebrates was monitored by placing four pitfall traps once in each field for $48 \mathrm{~h}$, on March 25th to April 24th. The traps consisted of $850 \mathrm{ml}$ plastic buckets dug down to ground level, with funnels and soap water to stop arthropods from escaping. We selected the three most common groups of ground-dwelling predators for analysis: ants (Hymenoptera: Formicidae), spiders (Arachnida: Araneae) and predatory beetles (rove and ground beetles; Coleoptera: Carabidae and Staphylinidae).
Parasitism and predation

As parasitoid wasps are known to be effective aphid biocontrol agents (Schmidt et al. 2003), aphid parasitism rate was estimated by counting alive and parasitized (mummified) aphids twice in each field, simultaneously with the pest abundance assessment previously described.

As a proxy for predation rates by ground-dwelling predators, diamondback moth egg clusters were placed on the ground in each field and removal rates were recorded after $24 \mathrm{~h}$. The moth eggs were obtained from the International Centre for Insect Physiology and Ecology (ICIPE) in Nairobi. They were collected 27th-28th March in Nairobi, were received on 1st April in Kitale and kept at $+8{ }^{\circ} \mathrm{C}$ until used in the experiment on 4th April (the experiment was run at all sites on the same day). Clutches of 10 ( \pm 3 ) eggs were glued (UHU Super Glue liquid Ultra fast) on white $1 \times 10 \mathrm{~cm}$ plastic labels. Five egg clutches were placed in each field with a minimum distance of $1 \mathrm{~m}$ between each clutch and attached to the ground with toothpicks, following the method described by Sandhu et al. (2008). One of the five clutches was enclosed within a $15 \times 15 \mathrm{~cm}$ mesh cage $(1 \times 2 \mathrm{~mm}$ mesh size $)$ as a control for desiccation and ambient egg survival without predators. All clutches were protected from rain by a round plastic cover $(\varnothing$ $23 \mathrm{~cm}$ ).

As bird predation has been found to reduce aphid populations, constrain parasitism and reduce plant damage by free-feeding caterpillars in other systems (Hooks et al. 2003; Martin et al. 2013; Ndang'ang'a et al. 2013), these variables were assessed by performing a bird exclusion experiment. Four pairs of kale plants per field were randomly selected. One plant from each pair was covered with a cage $(45 \mathrm{~cm} \times 45 \mathrm{~cm} \times 55 \mathrm{~cm}$, nylon bird mesh, mesh size $4 \mathrm{~cm}$ ) and one was left uncaged as a control. The minimum distance between plants in each pair was $1 \mathrm{~m}$ and between pairs it was $2 \mathrm{~m}$. On each plant, three top leaves and three bottom leaves were selected for assessing pest abundance. Living and mummified aphids were counted on half of the leaves and plant damage by chewing arthropods was estimated on the other half. The proportion of leaf damage was visually estimated with the following scale: $0,0-10,10-25$, 25-50, 50-75 and 75-100\%. Leaf herbivory and aphid numbers were assessed before placing the cages and 
after the 7-day experimental period. The experiment was conducted twice on different plants with a minimum of 5 days' interval between the trials, with the first trial from 11th-28th March and the second from 1st-18th April.

Attack rates on caterpillars were estimated by placing out one surrogate caterpillar on each of ten randomly selected plants per field (each plant a minimum of $1 \mathrm{~m}$ apart). The caterpillars were made of non-toxic green plasticine (brand Pilens plastilina), $\sim 40 \mathrm{~mm}$ in length and 3-5 $\mathrm{mm}$ in diameter. Surrogate caterpillars have been successfully used for predation assessments in other systems and the method has been found efficient for comparing relative attack rates between different habitats (e.g. Loiselle and Farji-Brener 2002; Howe et al. 2009). The experiment was conducted twice on different plant individuals, with a minimum of 12 days' between the trials, with the first running 11th-28th March, and the second 1st23rd April. Attack marks were recorded after 7 days. All marks were recorded in the field using a $10 \times$ magnifying glass and were photographed for later identification. Attack marks were identified according to Howe et al. (2009) and Tvardikova and Novotny (2012). Data was summarized as presence/absence of marks for each predatory group, namely birds, predatory beetles, rodents and parasitoids, on each surrogate caterpillar. The disappearance rate of caterpillars was relatively low, with an average of $6.25 \%$ and a maximum of $30 \%$. Non-recovered caterpillars were excluded from the analysis.

\section{Statistical analysis}

Before testing the effect of shade trees, we examined whether bird predation had an effect on aphid abundance, aphid parasitism rates and plant damage with a Mann-Whitney nonparametric test. The impact of bird predation on aphid populations was then quantified as the difference in aphid population growth rate between treatments with birds present and birds excluded. The aphid growth rate was estimated by the linear regression between day and $\log _{\mathrm{e}}$ of the number of aphids per leaf, with the following formula: $\Delta r=r_{\text {(exclusion cages) }}$ $-r_{\text {(open plants) }}$ (Östman et al. 2001). Leaves with no aphids on them at the start of the experiment were excluded from the analysis.

To test whether ground-dwelling arthropods were predating on moth eggs, we compared disappearance rates of caged and open egg clusters with MannWhitney nonparametric tests using SPSS v.20 (IBM Corp. 2011).

To test the effect of shade trees on different response variables related to pest control, we fitted generalized linear mixed-effect models (lme4 package, Bates et al. 2015) with the statistical program $R$ v.3.3.2 (R Core Team 2017). The response variables, all averaged at field level, included the number of aphids per leaf, the abundances of free-feeding caterpillars and activity density of predators (ants, spiders, predatory beetles analysed separately and spiders and predatory beetles pooled), egg predation rates, the impact of bird predation on aphid population growth rate $(\Delta \mathrm{r})$, the proportion of surrogate caterpillars attacked by predatory beetles, birds, rodents and parasitoids, and aphid parasitism rate. Models with all possible combinations of the following random variables were fitted: sampling date, pesticide use during the experiment and use of mulching practices, the two latter nested within settlement. For response variables expressed as proportions we used models with a binomial error distribution with an observation level vector to adjust for over-dispersion (Bolker et al. 2009). For variables expressed as counts we used a negative binomial distribution and for $\Delta r$ and the logtransformed number of aphids per leaf we used a gaussian distribution (Table 1). For each response variable, we then used a model simplification procedure to select the models that best explained the variation of the data, by comparing all models according to the Akaike Information Criterion adjusted for small sample size (AICc) with the aictab function (AICcmodavg package, Mazerolle 2016). Competing models were those with a difference in $\mathrm{AICc}$ relative to the best $\mathrm{AICc}$ score $(\triangle \mathrm{AICc})$ equal to or lower than two.

\section{Results}

Invertebrate population surveys

We counted a total of 24,352 aphids and 40 freefeeding moth caterpillars on the plants. The presence of shade trees significantly reduced mean aphid abundance $(p=0.00002$ and $p=0.00003$ respectively for the two competing best-fit models, Table 1 , 
Table 1 Error distribution, random variables included and statistical output for each of the best-fitting generalized linear models testing the effect of shade on pest and natural enemy abundances, parasitism and predation

\begin{tabular}{|c|c|c|c|c|c|c|}
\hline Response variable & Error distribution & Random variable(s) & Estimate & SE & $\mathrm{Z}$ value & $\mathrm{p}$ value \\
\hline \multicolumn{7}{|l|}{ Pest abundances } \\
\hline Aphids per leaf, model 1 & $\begin{array}{l}\text { Gaussian }(\log - \\
\text { transformed) }\end{array}$ & Sampling date & -1.2398 & 0.2899 & $\begin{array}{l}\text { ( } \mathrm{t} \text { value }) \\
-4.2765\end{array}$ & $0.00002 * * *$ \\
\hline Aphids per leaf, model 2 & $\begin{array}{l}\text { Gaussian }(\log - \\
\text { transformed) }\end{array}$ & & -1.2967 & 0.3132 & $\begin{array}{l}\text { ( } \mathrm{t} \text { value }) \\
-4.1397\end{array}$ & $0.00003 * * *$ \\
\hline Caterpillars & Negative binomial & Sampling date & -1.0245 & 0.3927 & -2.609 & $0.00908 * *$ \\
\hline \multicolumn{7}{|l|}{ Predator abundances } \\
\hline Ants & Negative binomial & Sampling date & 0.4334 & 0.3262 & 1.329 & 0.184 \\
\hline Spiders & Negative binomial & Sampling date & 0.5766 & 0.3074 & 1.876 & 0.0607 \\
\hline Predatory beetles & Negative binomial & Sampling date & 0.8248 & 0.7269 & 1.135 & 0.256 \\
\hline $\begin{array}{l}\text { Pooled spiders and predatory } \\
\text { beetles, model } 1\end{array}$ & Negative binomial & Sampling date & 0.6014 & 0.2508 & 2.397 & $0.0165^{*}$ \\
\hline $\begin{array}{l}\text { Pooled spiders and predatory } \\
\text { beetles, model } 1\end{array}$ & Negative binomial & Pesticide & 0.7370 & 0.2550 & 2.890 & $0.00385^{* *}$ \\
\hline Aphid parasitism rates & Binomial & $\begin{array}{l}\text { Pesticide, observation } \\
\text { level factor }\end{array}$ & 0.0654 & 0.4099 & 0.16 & 0.873 \\
\hline Moth egg removal rates & Binomial & $\begin{array}{l}\text { Observation level } \\
\text { factor }\end{array}$ & -0.05836 & 0.22678 & -0.257 & 0.797 \\
\hline $\begin{array}{l}\text { Bird predation on aphids, model } \\
1\end{array}$ & Gaussian & Sampling date & 0.009355 & 0.067950 & $\begin{array}{l}\text { (t value) } \\
0.138\end{array}$ & 0.890 \\
\hline $\begin{array}{l}\text { Bird predation on aphids, model } \\
2\end{array}$ & Gaussian & Mulching & 0.02141 & 0.06621 & $\begin{array}{l}\text { (t value) } \\
0.323\end{array}$ & 0.890 \\
\hline \multicolumn{7}{|l|}{ Surrogate caterpillar attacks by } \\
\hline Birds, model 1 & Binomial & $\begin{array}{l}\text { Observation level } \\
\text { factor }\end{array}$ & 0.2659 & 0.2848 & 0.934 & 0.35 \\
\hline Birds, model 2 & Binomial & Sampling date & 0.2740 & 0.2872 & 0.954 & 0.34 \\
\hline Invertebrates & Binomial & Sampling date & 0.01846 & 0.2503 & 0.074 & 0.941 \\
\hline Rodents (model 1) & Binomial & $\begin{array}{l}\text { Observation level } \\
\text { factor }\end{array}$ & 0.8694 & 0.6669 & 1.304 & 0.192 \\
\hline Rodents (model 2) & Binomial & Sampling date & 0.8774 & 0.6757 & 1.299 & 0.194 \\
\hline Parasitoids (model 1) & Binomial & $\begin{array}{l}\text { Observation level } \\
\text { factor }\end{array}$ & 0.04351 & 0.54839 & 0.079 & 0.937 \\
\hline Parasitoids (model 2) & Binomial & Sampling date & 0.04674 & 0.46901 & 0.100 & 0.921 \\
\hline
\end{tabular}

$* p<0.05 ; * * p<0.01 ; * * * P<0.001$

Fig. 3a) as well as the abundances of caterpillars ( $\mathrm{p}=0.00908$, Table 1, Fig. 3b).

In total, 2081 ants, 222 spiders and 48 rove and ground beetles were caught in the pitfall traps. Shade did not affect the abundance of any of the grounddwelling predator groups when analysed individually, but significantly increased the pooled abundance of spiders and predatory beetles $(\mathrm{p}=0.0165$ and $\mathrm{p}=0.00385$ respectively for the two competing best-fit models, Table 1, Fig. 4), with a potential impact of pesticide use as the latter was retained as a random variable improving model fit.

Parasitism and predation

For estimating aphid parasitism rate, we recorded a total of 24,352 living and mummified aphids on the plants. The overall parasitism rate was very low, $0.91 \%$. It was not affected by shade, but pesticide use 
Fig. 3 Number per field of a aphids per leaf $(n=40)$, with each dot representing the average number per leaf per field, and $\mathbf{b}$ moth caterpillars $(n=20)$, with each dot representing the total abundance per field, in open and shaded fields. Boxes show median and interquartile ranges for each site type, with the whiskers extending to 1.5 of the interquartile range (a) aphids

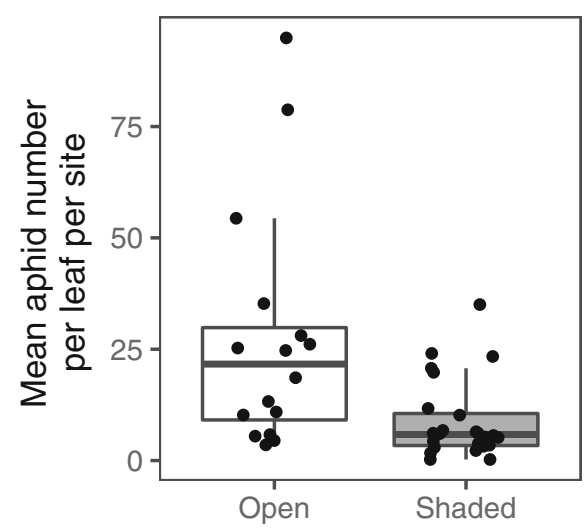

field of $\mathbf{a}$ ants $(\mathrm{n}=20)$, b spiders $(n=20)$ and c predatory beetles $(n=20)$ and pooled spiders and predatory beetles $(n=20)$ in open and shaded fields. Each dot represents the total activity density in a field, boxes show median and interquartile ranges for each site type, with the whiskers extending to 1.5 of the interquartile range (a) ants

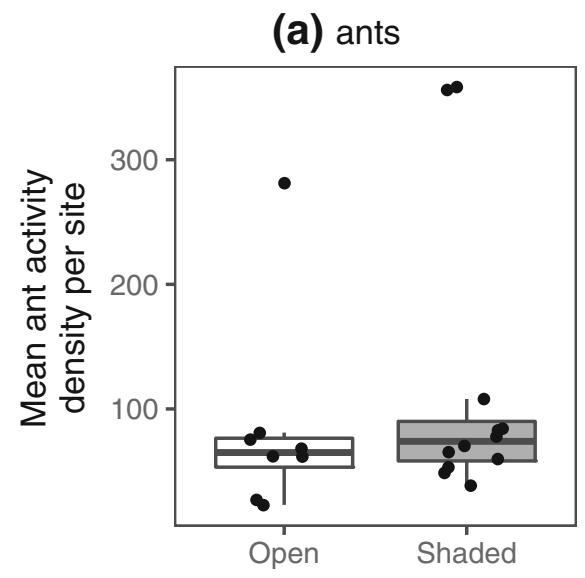

(c) predatory beetles

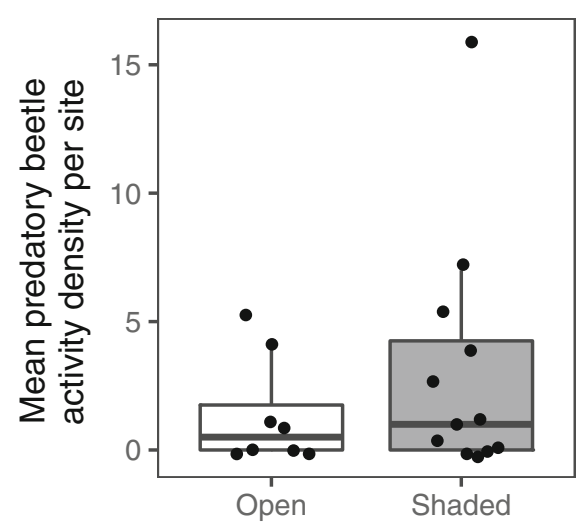

(b) caterpillars

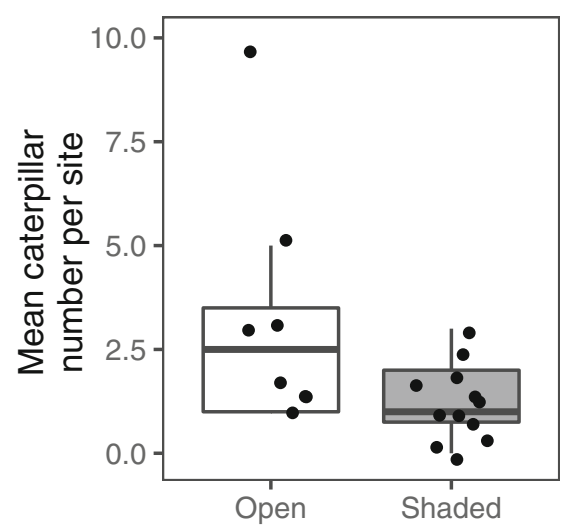

(b) spiders

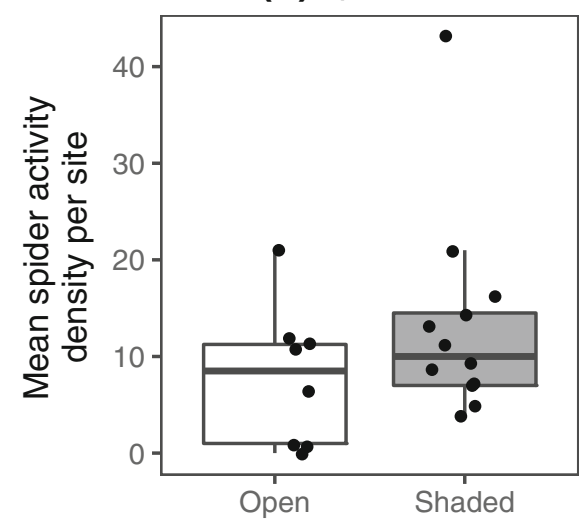

(d) spiders and predatory beetles

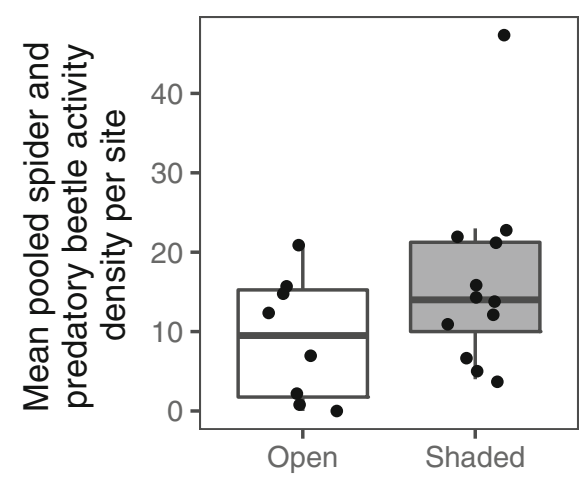

was retained as a random variable improving the model fit (Table 1, Fig. 5).

The difference between disappearance of eggs in caged control treatments and in open treatments indicated significant predation by ground-dwelling predators (Mann-Whitney, $\mathrm{U}=485.5, \mathrm{n}=100$, $\mathrm{p}=0.001$ ), with the egg disappearance rate being $56.6 \%$ higher in the un-caged treatments (Fig. 6a). However, shade did not explain the variation in egg disappearance rates (Table 1, Fig. 7a). The exclusion 


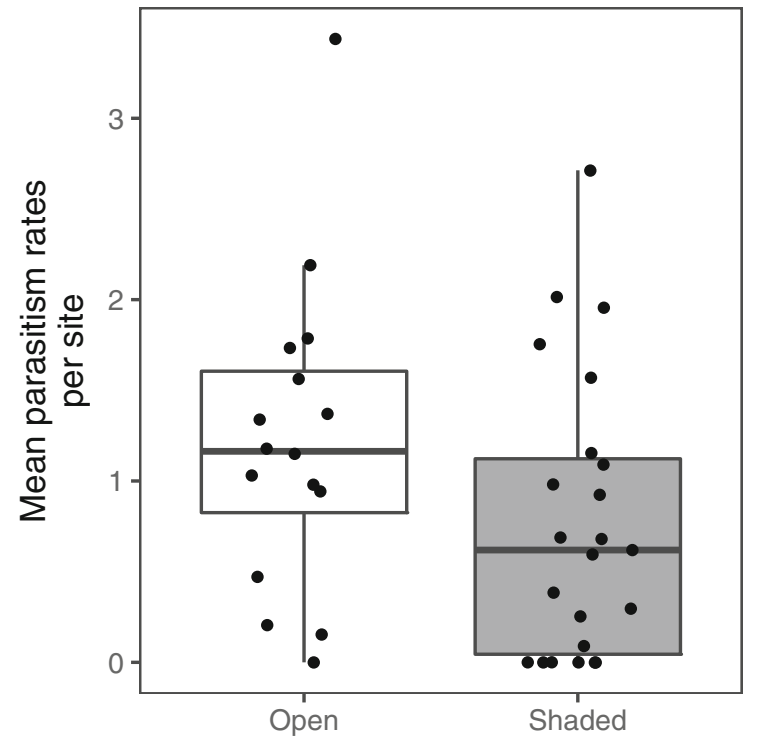

Fig. 5 Aphid parasitism rate $(n=40)$ in open and shaded fields. Each dot represents the average parasitism rate of a field, boxes show median and interquartile ranges for each site type, with the whiskers extending to 1.5 of the interquartile range

of birds from kale plants increased aphid abundance (Mann-Whitney, $\mathrm{U}=10,355.5, \mathrm{n}=313, \mathrm{p}=0.018$; Fig. 5b), but had no effect on herbivore-related leaf damage or on aphid parasitism rates. Bird predation on aphids was not affected by shade trees (Table 1, Fig. 7b). Surrogate caterpillars were most commonly attacked by invertebrate predators (mean \pm SE proportion of caterpillars, $0.254 \pm 0.024)$, followed by birds $(0.171 \pm 0.020)$, parasitoids $(0.055 \pm 0.012)$ and finally by rodents $(0.034 \pm 0.007)$. Attacks on surrogate caterpillars were not affected by shade (Table 1, Fig. 8).

\section{Discussion}

Our study demonstrated that presence of shade trees, inside or directly adjacent to kale fields, can reduce aphid and caterpillar pest populations on kale and increase abundances of ground-dwelling predators. However, we found no direct evidence that biological control was affected by shade, as neither predationnor parasitism rates were affected by the presence of shade trees. This indicates that biological control by natural enemies was not the only mechanism behind reduced pest populations when shade trees were present, but that effects of microclimate on pest performance and bottom-up effects on pests, such as via changes in plant quality or soil conditions, were likely to have been important as well.

\section{Effect of shade on biological control}

We found no effects of shade on predation rates and aphid parasitism rates in agroforestry systems compared to monocultures, thus not supporting several previous studies finding increased aphid parasitism rates (Alignier et al. 2014) and bird predation rates (e.g. Perfecto et al. 2004; Karp et al. 2013) in agroforestry systems, compared to monocultures. However, we did find that pooled abundances of ground-dwelling predatory beetles and spiders increased with shade. Although not a direct assessment of predation pressure, this increase in activity density of certain groups of natural enemies is consistent with most other studies (Pumariño et al. 2015) and indicates that biological control might still be part of the explanation between the reduced pest
Fig. 6 a Egg disappearance rate $(n=100)$ and b differences in aphid numbers $(\mathrm{n}=313)$ in uncaged and caged treatments. Each dot represents the average disappearance rate per field and difference in numbers per field, boxes show median and interquartile ranges for each site type, with the whiskers extending to 1.5 of the interquartile range (a) egg predation by arthropods

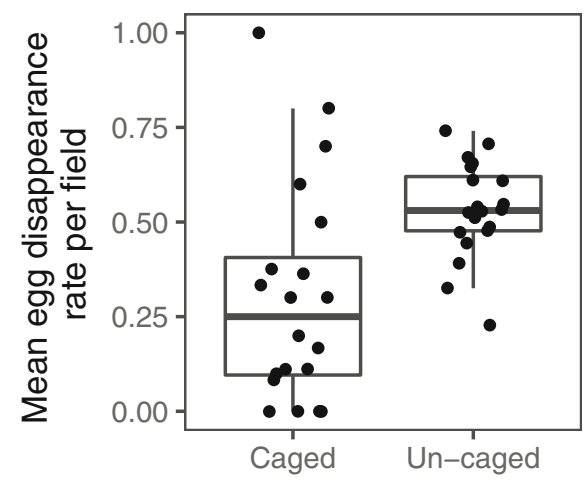

(b) aphid predation by birds

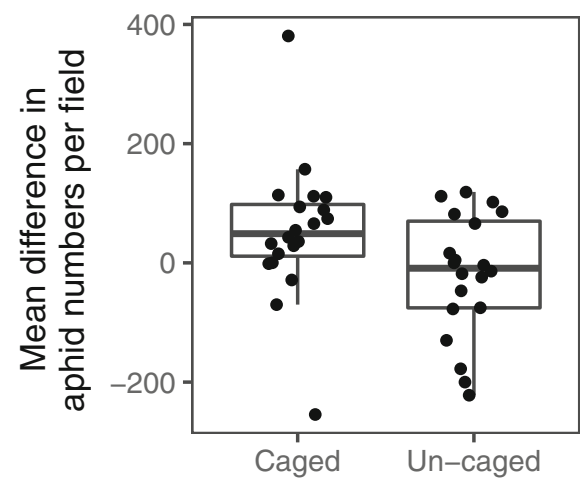


Fig. 7 a Egg disappearance rate $(n=20)$, b bird predation rate $(\mathrm{n}=36)$ in open and shaded fields. Each dot represents the

disappearance rate per field and difference in numbers per field, boxes show median and interquartile ranges for each site type, with the whiskers extending to 1.5 of the interquartile range

Fig. 8 Number of attacks on surrogate caterpillars by a birds $(n=40)$,

b invertebrates $(\mathrm{n}=40)$, c rodents $(n=40)$, and d parasitoids $(\mathrm{n}=40)$ in shaded and open fields. Each dot represents the number of attacks per field, boxes show median and interquartile ranges for each site type, with the whiskers extending to 1.5 of the interquartile range

\section{(a) shade effect on aphid predation}

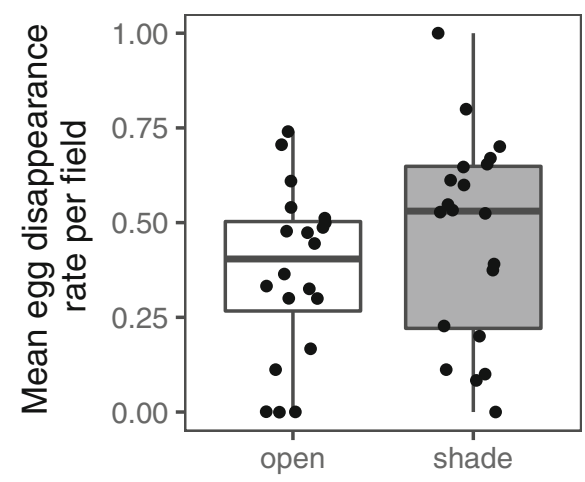

(a) bird predation on caterpillars

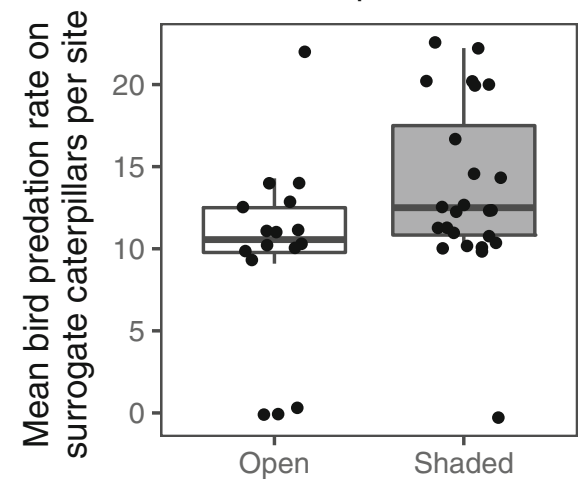

(c) rodent predation

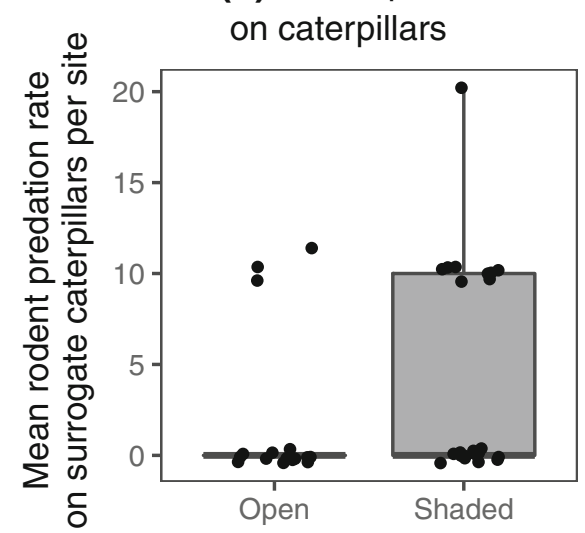

(b) shade effect on bird predation

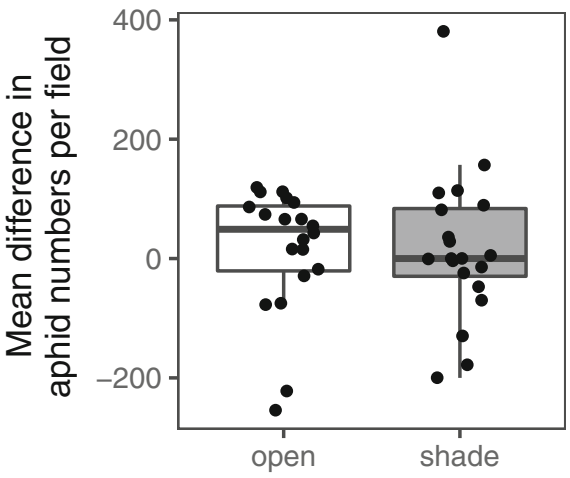

(b) invertebrate predation on

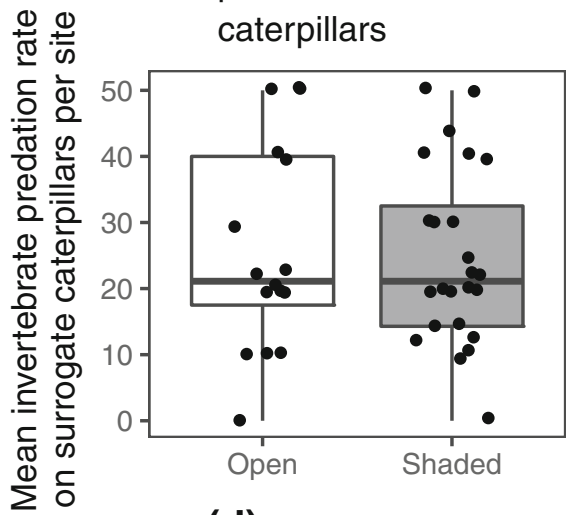

(d) parasitism on caterpillars

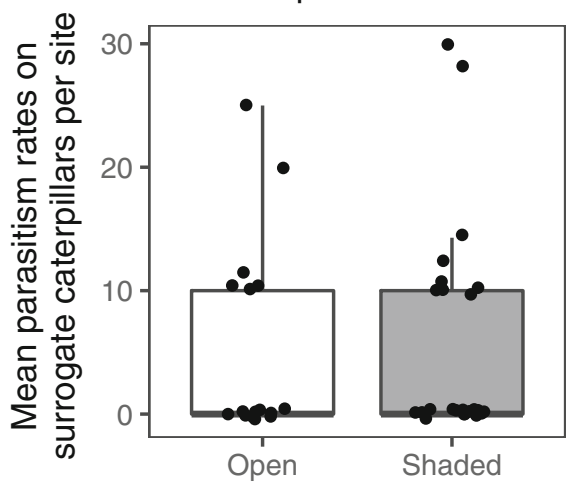

abundances in shady conditions. It should be noted however, that all our estimates of abundances and predation rates were snap-shots, and longer-term studies will be critical to properly evaluate the importance of biological control in this system.
Moreover, the incorporation of more precise measures of pesticide use could be relevant as it affected both pooled predator abundances and parasitism rates in our study and is known to have strong effects on biocontrol services in general (Geiger et al. 2010). 
Microclimatic and bottom-up effects of shade on pests

Because no conclusive effect of shade on biological control potential was detected, it is likely that other factors also contributed to the reduction in pest numbers. Shade induces changes in microclimate, which can have direct effects on invertebrate physiology and thereby regulate their populations. For example, invertebrate reproductive rates are usually lower in cooler conditions, and may also be affected by humidity (Burgess et al. 1996; Chaplin-Kramer and Kremen 2012). Moreover, most insects, including aphids, use olfactory cues to locate their host plants. Incorporation of trees in agroecosystems modifies wind speed and direction, and this may influence the crop's olfactory signals for pest host location (Rao et al. 2000; Moser et al. 2009).

Furthermore, the decreased temperature and increased humidity under shaded conditions can have an impact on plant quality and palatability, which may influence pest abundances. Shade can decrease the rate of photosynthesis (Sleeman and Dudley 2001), alter plant biomass, plant height, leaf area and protein content, and alter plant chemical composition (Olsson et al. 1998; Sleeman and Dudley 2001; Barber and Marquis 2011). Chemical changes induced by shade include the decrease in phenolic compounds, known to be important for plant defence (Barber and Marquis 2011). Shade trees may also modify a crop's nutritional quality by either depleting soil nutrients following competition between crops and trees or by increasing fertilization by nitrogen-fixing trees (Rao et al. 2000). Plant nutritional quality can also be altered by decreased water stress induced by shading (Barber and Marquis 2011). Low water stress can decrease the soluble nitrogen content in brassica crops, while nitrogen is often a limiting factor for population growth of many insect pests (Burgess et al. 1996).

\section{Effects of bird predation on pests}

In our study, avian predation decreased aphid abundance, but had no effect on leaf damage by chewing herbivores. This result may seems surprising, as birds are known to decrease free-feeding caterpillar abundances and their leaf damage in kale agroecosystems (Hooks et al. 2003; Ndang'ang'a et al. 2013). However, similarly significant avian predation on aphids has been observed in kale fields of other regions of Kenya, yet only during the dry season (Ndang'ang'a et al. 2013). This difference in predation pressure with relation to the season cautions that effects found in a single season such as with our study can not necessarily be generalised as year-round mechanisms.

Despite the beneficial effect of birds in reducing aphid abundances, the avian fauna is often considered harmful by local farmers, because some bird species are considered as pests, feeding on cereals and vegetables and spreading weeds and diseases (Chitere and Omolo 1993). Showing that birds can reduce pest damage by predation is thus of importance for promoting bird conservation.

\section{Conclusion}

This study provided further evidence that agroforestry can be used to regulate crop pests (Schroth et al. 2000; Pumariño et al. 2015), as presence of shade trees reduced populations of both aphids and caterpillars on kale. However, in contrast to many other studies, our work found no conclusive evidence of more effective biological control by natural enemies in shady habitats (although abundances of ground-dwelling predators did increase with agroforestry practices). Direct effects of changes in microclimate on pest physiology as well as bottom-up effects mediated by changes in plant or soil quality were likely also part of the mechanism behind pest reduction-although they were not explicitly measured in our study. Further research is needed to disentangle more clearly the relative importance of top-down and bottom-up mechanisms behind the often observed reductions in pest populations under agroforestry management, and to assess how these effects vary within and among seasons.

Acknowledgements We are thankful to Vi-Agroforestry in Kitale for assistance with fieldwork logistics and contact with farmers, to Dr. C. Midega from the ICIPE for providing us with diamondback moth eggs, to O. Cleophas, P. Springe and S. Wanjiru for their help with fieldwork and to Dr. M. Dallimer from the Sustainability Research Institute, University of Leeds, for his comments on the statistics. M. Jonsson is grateful for funds from Centre for Biological Control at the Swedish University of Agricultural Sciences.

Open Access This article is distributed under the terms of the Creative Commons Attribution 4.0 International License (http:// 
creativecommons.org/licenses/by/4.0/), which permits unrestricted use, distribution, and reproduction in any medium, provided you give appropriate credit to the original author(s) and the source, provide a link to the Creative Commons license, and indicate if changes were made.

\section{References}

Alignier A, Raymond L, Deconchat M et al (2014) The effect of semi-natural habitats on aphids and their natural enemies across spatial and temporal scales. Biol Control 77:76-82. https://doi.org/10.1016/j.biocontrol.2014.06.006

Badenes-Perez FR, Shelton AM (2006) Pest management and other agricultural practices among farmers growing cruciferous vegetables in the Central and Western highlands of Kenya and the Western Himalayas of India. Int J Pest Manag 52:303-315. https://doi.org/10.1080/ 09670870600819169

Barber NA, Marquis RJ (2011) Light environment and the impacts of foliage quality on herbivorous insect attack and bird predation. Oecologia 166:401-409. https://doi.org/10. 1007/s00442-010-1840-9

Bates D, Maechler M, Bolker B, Walker S (2015) Fitting linear mixed-effects models using "lme4". J Stat Softw 67:1-48. https://doi.org/10.18637/jss.v067.i01

Bianchi FJJA, Booij CJH, Tscharntke T (2006) Sustainable pest regulation in agricultural landscapes: a review on landscape composition, biodiversity and natural pest control. Proc R Soc B Biol Sci 273:1715-1727. https://doi.org/10. 1098/rspb.2006.3530

Bisseleua HBD, Fotio D, Yede et al (2013) Shade tree diversity, cocoa pest damage, yield compensating inputs and farmers' net returns in West Africa. PLoS ONE. https://doi.org/ 10.1371/journal.pone.0056115

Bolker BM, Brooks ME, Clark CJ et al (2009) Generalized linear mixed models: a practical guide for ecology and evolution. Trends Ecol Evol 24:127-135. https://doi.org/ 10.1016/j.tree.2008.10.008

Bommarco R, Kleijn D, Potts SG (2013) Ecological intensification: harnessing ecosystem services for food security. Trends Ecol Evol 28:230-238. https://doi.org/10.1016/j. tree.2012.10.012

Burgess AJ, Warrington S, Allen-Williams L (1996) Cabbage aphid (Brevicoryne brassicae L.) "performance" on oilseed rape (Brassica napus L.) experiencing water deficits: roles of temperature and food quality. In: International symposium on Brassicas ninth crucifer genetics workshop, pp 499-505

Chaplin-Kramer R, Kremen C (2012) Pest control experiments show benefits of complexity at landscape and local scales. Ecol Appl 22:1936-1948

Chitere PO, Omolo BA (1993) Farmers indigenous knowledge of crop pests and their damage in Western Kenya. Int J Pest Manag 39:126-132. https://doi.org/10.1080/0967087930 9371776

Corp IBM (2011) IBM SPSS Statistics for Windows. IBM Corp, Armonk
Dunning JB, Danielson BJ, Pulliam HR (1992) Ecological processes that affect populations in complex landscapes. Oikos 65:169-175. https://doi.org/10.2307/3544901

Foley JA, DeFries R, Asner GP et al (2005) Global consequences of land use. Science 309:570-574. https://doi.org/ 10.1126/science. 1111772

Geiger F, Bengtsson J, Berendse F et al (2010) Persistent negative effects of pesticides on biodiversity and biological control potential on European farmland. Basic Appl Ecol 11:97-105

Hooks CRR, Pandey RR, Johnson MW (2003) Impact of avian and arthropod predation on lepidopteran caterpillar densities and plant productivity in an ephemeral agroecosystem. Ecol Entomol 28:522-532. https://doi.org/10.1046/j.13652311.2003.00544.x

Howe A, Lovei GL, Nachman G (2009) Dummy caterpillars as a simple method to assess predation rates on invertebrates in a tropical agroecosystem. Entomol Exp Appl 131:325-329. https://doi.org/10.1111/j.1570-7458.2009.00860.x

Jaetzold R, Schmidt H, Hornetz B, Shisanya C (2006) Natural conditions and farm management information, part BCentral Kenya, 2nd edn. Ministry of Agriculture, Kenya, in Cooperation with the German Agency for Technical Cooperation (GTZ), Nairobi

Karp DS, Mendenhall CD, Sandi RF et al (2013) Forest bolsters bird abundance, pest control and coffee yield. Ecol Lett 16:1339-1347. https://doi.org/10.1111/ele.12173

Kibata GN (1997) The diamondback moth: a problem pest of brassica crops in Kenya. In: Sivapragasam A, Loke WH, Hussan AK, Lim GS (eds) The management of diamondback moth and other crucifer pests. Proceedings of the third international workshop, 29 October-1 November 1996, Kuala Lumpur, Malaysia. Malaysian Agricultural Research and Development Institute (MARDI), pp 47-53

Kuyah S, Öborn I, Jonsson M et al (2016) Trees in agricultural landscapes enhance provision of ecosystem services in Sub-Saharan Africa. Int J Biodivers Sci Ecosyst Serv Manag 3732:1-19. https://doi.org/10.1080/21513732. 2016.1214178

Landis DA, Wratten SD, Gurr GM (2000) Habitat management to conserve natural enemies of arthropod pests in agriculture. Annu Rev Entomol 45:175-201. https://doi.org/10. 1146/annurev.ento.45.1.175

Loiselle BA, Farji-Brener AG (2002) What's up? An experimental comparison of predation levels between canopy and understory in a tropical wet forest. Biotropica 34:327-330. https://doi.org/10.2307/4132909

Lundgren B (1982) What is agroforestry? Agrofor Syst 1:7-12. https://doi.org/10.1007/BF00044325

Martin EA, Reineking B, Seo B, Steffan-Dewenter I (2013) Natural enemy interactions constrain pest control in complex agricultural landscapes. Proc Natl Acad Sci USA 110:5534-5539

Matson PA, Parton WJ, Power AG, Swift MJ (1997) Agricultural intensification and ecosystem properties. Science 277:504-509. https://doi.org/10.1126/science.277.5325. 504

Mazerolle MJ (2016) AICcmodavg: model selection and multimodel inference based on (Q)AIC(c)

Moser D, Drapela T, Zaller JG, Frank T (2009) Interacting effects of wind direction and resource distribution on insect 
pest densities. Basic Appl Ecol 10:208-215. https://doi. org/10.1016/j.baae.2008.03.008

Ndang'ang'a PK, Njoroge JBM, Vickery J (2013) Quantifying the contribution of birds to the control of arthropod pests on kale, Brassica oleracea acephala, a key crop in East African highland farmland. Int J Pest Manag 59:211-216. https://doi.org/10.1080/09670874.2013.820005

Nyambo BT, Masaba DM, Hakiza GJ (1996) Integrated pest management of coffee for small-scale farmers in East Africa: needs and limitations. Integr Pest Manag Rev 1:125-132. https://doi.org/10.1007/BF00130671

Olsson LC, Veit M, Weissenbock G, Bornman JF (1998) Differential flavonoid response to enhanced UV-B radiation in Brassica napus. Phytochemistry 49:1021-1028. https:// doi.org/10.1016/s0031-9422(98)00062-4

Östman O, Ekbom B, Bengtsson J (2001) Landscape heterogeneity and farming practice influence biological control. Basic Appl Ecol 2:365-371. https://doi.org/10.1078/14391791-00072

Perfecto I, Vandermeer JH, Bautista GL et al (2004) Greater predation in shaded coffee farms: the role of resident neotropical birds. Ecology 85:2677-2681. https://doi.org/ 10.1890/03-3145

Pumariño L, Sileshi GW, Gripenberg S et al (2015) Effects of agroforestry on pest, disease and weed control: a metaanalysis. Basic Appl Ecol. https://doi.org/10.1016/j.baae. 2015.08.006

R Core Team (2017) R: a language and environment for statistical computing. R Foundation for Statistical Computing, Vienna

Rao MR, Singh MP, Day R (2000) Insect pest problems in tropical agroforestry systems: contributory factors and strategies for management. Agrofor Syst 50:243-277. https://doi.org/10.1023/a:1006421701772

Salasya B, Burger K (2010) Determinants of the place of sell and price of kale for Kiambu, Kenya. Afr J Agric Res 5:805-812. https://doi.org/10.5897/ajar09.680

Sandhu HS, Wratten SD, Cullen R, Case B (2008) The future of farming: the value of ecosystem services in conventional and organic arable land. An experimental approach. Ecol Econ 64:835-848. https://doi.org/10.1016/j.ecolecon. 2007.05.007

Schmidt MH, Lauer A, Purtauf T et al (2003) Relative importance of predators and parasitoids for cereal aphid control. Proc R Soc B Biol Sci 270:1905-1909. https://doi.org/10. 1098/rspb.2003.2469

Schroth G, Krauss U, Gasparotto L et al (2000) Pests and diseases in agroforestry systems of the humid tropics. Agrofor Syst 50:199-241. https://doi.org/10.1023/a: 1006468103914

Sleeman JD, Dudley SA (2001) Phenotypic plasticity in carbon acquisition of rapid cycling Brassica rapa $\mathrm{L}$. in response to light quality and water availability. Int $\mathrm{J}$ Plant Sci 162:297-307. https://doi.org/10.1086/319584

Tscharntke T, Clough Y, Bhagwat SA et al (2011) Multifunctional shade-tree management in tropical agroforestry landscapes-a review. J Appl Ecol 48:619-629. https:// doi.org/10.1111/j.1365-2664.2010.01939.x

Tvardikova K, Novotny V (2012) Predation on exposed and leaf-rolling artificial caterpillars in tropical forests of Papua New Guinea. J Trop Ecol 28:331-341. https://doi.org/10. 1017/s0266467412000235 